\title{
Sarang Dolichoderus thoracicus pada Buah-Buahan Musiman di Perkebunan Masyarakat Kecamatan Sirah Pulau Padang
}

\author{
Ari Sugiarto \\ Email: sugiartoari13@gmail.com
}

\begin{abstract}
Abstrak
Dolichoderus thoracicus merupakan spesies semut yang umum dijumpai. Keberadaan D. thoracicus pada tanaman dapat memperkecil potensi ancaman dari serangga terutama serangga perusak buah. Perkebunan masyarakat di kecamatan Sirah Pulau Padang banyak ditanam tanaman musiman yang tentunya memiliki potensi ancaman dari serangga perusak buah. Perlu dilakukan pengamatan sarang D. thoracicus pada buah-buahan musiman di perkebunan masyarakat kecamatan Sirah Pulau Padang untuk memperkirakan potensi ancaman dari serangga perusak buah. Pengamatan ini dilakukan pada bulan Januari 2019 dengan mengamati buah-buahan musiman yang terdapat di perkebunan masyarakat. Hasil pengamatan yang dilakukan, ditemukan sarang $D$. thoracicus pada buah manggis dan rambutan, ditemukan juga koloni $D$. thoracicus pada buah duku dan raman. Keberadaan sarang dan koloni D. thoracicus pada buah manggis, rambutan, duku, dan raman dapat diperkirakan potensi ancaman dari serangga perusak buah yang lebih kecil dibanding pada buah-buahan musiman lainnya di perkebunan masyarakat Kecamatan Sirah Pulau Padang.
\end{abstract}

Kata kunci: Buah-buahan musiman, Dolichoderus thoracicus, Kecamatan Sirah Pulau Padang, Perkebunan masyarakat

\section{Pendahuluan}

Dolichoderus thoracicus merupakan spesies semut yang umum dijumpai, ini dikarenakan $D$. thoracicus tersebar secara luas. Menurut Wiryadiputra (2007), Anshary dan Flora (2008), dan Murnawati et al. (2018), D. thoracicus dapat menjadi agen pengendali hayati yang cukup efisien untuk menanggulangi hama pada tanaman perkebunan dan predator bagi Conopomorpha cramerella, Helopeltis spp. dan hama lainnya.

Perkebunan masyarakat di Kecamatan Sirah Pulau Padang banyak ditanam tanaman musiman yaitu Durio zibethinus, Lansium domesticum, Garcinia mangostana, Nephelium lappaceum, Baccaurea motleyana, dan Bouea macrophylla (Sugiarto, 2019). Keberadaan D. thoracicus pada buah-buahan musiman di perkebuanan masyarakat ini akan sangat membantu memperkecil potensi ancaman dari serangga perusak buah, oleh karena itu perlu dilakukan pengamatan keberadaan sarang semut pada buah-buahan musiman di pekerbunan masyarakat Kecamatan Sirah Pulau Padang. Hasil dari pengamatan ini dapat membantu dalam memperkirakan potensi ancaman dari serangga perusak buah terhadap buah-buahan musiman pada perkebuanan masyarakat.

\section{Metode Penelitian}

Pengamatan ini dilakukan pada bulan Januari 2019, bertempat di Kecamatan Sirah Pulau Padang, Kabupaten Ogan Komering Ilir, Sumatera Selatan. Pengamatan dilakukan dengan mengamati buah-buahan musiman yang terdapat di perkebunan masyarakat apakah ditemukan sarang atau koloni D.thoracicus. Selain itu, diamati juga bagian buah yang ditemukan sarang atau koloni D. thoracicus. Menurut Sugiarto (2018), musim panen pada pekebunan masyarakat di Kecamatan Sirah Pulau Padang dimulai dari bulan Desember-Maret. Data hasil pengamatan disajikan dalam bentuk paragraf deskriptif. 


\section{Hasil dan Pembahasan}

Berdasarkan hasil pengamatan yang dilakukan pada perkebunan masyarakat di Kecamatan Sirah Pulau Padang, ditemukan sarang D. thoracicus pada buah manggis (Garcinia mangostana) dan rambutan (Nephelium lappaceum). Ditemukan juga koloni D. thoracicus pada buah duku (Lansium domesticum) dan raman (Bouea macrophylla). Tidak ditemukan sarang atau koloni $D$. thoracicus pada buah durian (Durio zibethinus) dan rambai (Baccaurea motleyana).

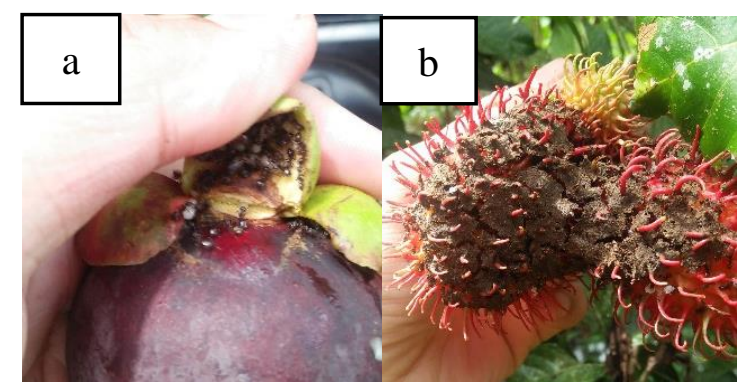

Gambar 1. Sarang Dolichoderus thoracicus pada buah a. manggis, b. rambutan

Sarang D. thoracicus yang ditemukan pada buah Manggis (Gambar 1) berada di bawah kelopak buah, sedangkan pada buah Rambutan (Gambar 1) ditemukan pada permukaan kulit luar yang banyak terdapat rambut-rambut. Terdapat perbedaan yang cukup mencolok sarang $D$. thoracicus pada buah Manggis dan Rambutan. Sarang D. thoracicus pada buah Manggis terdapat sedikit material yang digunakan untuk membuat sarang, sedangkan material yang digunakan untuk membuat sarang pada buah Rambutan lebih banyak. Material sarang $D$. thoracicus pada buah manggis yang sedikit diperkira hanya digunakan untuk melekatkan kelopak dengan kulit buah, sedangkan Material sarang yang lebih banyak buah rambuatan ini diperkirakan karena pada buah Rambutan tidak memiliki kelopak buah sehingga $D$. thoracicus membutuhkan lebih banyak material untuk membuat sarang. Material sarang D. thoracicus pada buah Rambutan dilekatkan pada rambut-rambut yang terdapat pada kulit buah, sehingga terdapat ruang yang dapat ditempati $D$. thoracicus. Menurut Anshary dan Flora (2008), D. Thoracicus cenderung tertarik berada pada tempat yang gelap.

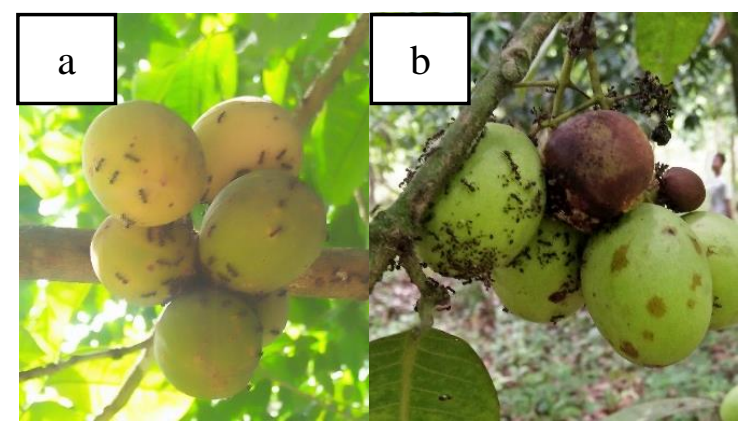

Gambar 2. Koloni Dolichoderus thoracicus pada buah a. duku, b. raman

Koloni D. thoracicus yang ditemukan pada buah duku dan raman (Gambar 2) berada di ruang antara buah dan tangkai buah. Menurut Anshary dan Flora (2008), perilaku $D$. thoracicus yang cenderung hidup berkoloni dikarenakan $D$. thoracicus cenderung hidup bergerombol pada tempat yang gelap atau intensitas cahaya rendah. Menurut Attygalle (1998), D. thoracicus berkomunikasi dengan feromon yang dihasilkan oleh kelenjar pavan.

Sarang atau koloni $D$. thoracicus tidak ditemukan secara menyeluruh pada setiap buah manggis, rambutan, duku, dan raman. Sarang D. thoracicus cenderung lebih mudah ditemukan buah manggis dibanding pada rambutan. Sarang $D$. thoracicus pada buah rambutan lebih cenderung ditemukan pada buah rambutan yang berada di bawah naungan dan pada varietas buah rambutan yang memiliki rambut-rambut yang panjang serta ukuran buah yang besar. Koloni D. thoracicus pada buah duku dan raman cenderung ditemukan pada buah yang berada dibawah naungan dan jumlah buah yang banyak dalam satu tangkai.

Memperbanyak koloni $D$. thoracicus pada tanaman dapat dilakukan dengan membuat sarang buatan, yaitu dengan menggunakan bambu, daun kelapa, dan gula merah sebagai sumber makanannya 
(Murnawati, 2018). Selain gula merah, Dolichoderus sp. juga tertarik dengan minyak kelapa (Sugiarto, 2018). Keberadaan D. thoracicus pada suatu tanaman dapat membantu menangulangi hama tanaman terutama pada buah (Murnawati, 2018), yaitu dengan menyelimuti permukaan buah (Wiryadiputra, 2007).

\section{Kesimpulan}

Keberadaan sarang dan koloni D. thoracicus pada buah manggis, rambutan, duku, dan raman dapat diperkirakan potensi ancaman serangga perusak buah yang lebih kecil dibanding pada buah durian dan rambai di perkebunan masyarakat Kecamatan Sirah Pulau Padang.

\section{Daftar Pustaka}

Anshary, A dan Flora, P. 2008. Teknik Perbanyakan Dan Aplikasi Predator Dolichoderus thoracicus (Smith) (Hymenoptera: Formicidae) Untuk Pengendalian Penggerek Buah Kakao Conopomorpha cramerella (Snellen) Di Perkebunan Rakyat. J. Agroland. 15(4): 278-287.

Attygalle, A.B. 1998. Trail Pheromone from the Pavan Gland of the Ant Dolichoderus thoracicus (Smith).
Naturwissenschaften. 85(1): 275277.

Murnawati., Annawaty., dan Umrah. 2018. Monitoring Ketahanan Hidup Semut Hitam Dolichoderus thoracicus Smith Pada Sarang Buatan Di Tanaman Kakao Biocelebes. 12(2):62-68.

Sugiarto, A. 2018. Utilization of Coconut Oil (Cocos nucifera L.) for Provoke The Presence of Ants (Hymenoptera: Formicidae). (Online). https://doi.org/10.31220/osf.io/45 gtj. Diakses pada tanggal 29 Januari 2019.

Sugiarto, A. 2019. Ecotourism Development Potential in Sirah Pulau Padang Sub-district Reviewed from the Society Plantation Sector. (Online). https://doi.org/10.31220/osf.io/xk 48v. Diakses pada tanggal 29 Januari 2019.

Wiryadiputra, S. 2007. Pemapanan Semut Hitam (Dolichoderus thoracicus) Pada Perkebunan Kakao dan Pengaruhnya Terhadap Serangan Hama Helopeltis spp. Pelita Perkebunan. 23(1), 57-71. 